\title{
Improvement of dry tropical rangelands on Hainan Island, China. 3. Legume response to initial fertilizer
}

\author{
DAVID L. MICHALK, FU NAN-PING, AND ZHU CHIN-MING
}

Authors are former director, former pasture technician, and production manager Gaopoling Model Cattle Farm, Ba Suo, Dong Fang County, Hainan Island, People's Republic of China.

\begin{abstract}
During 1981-83, we identified nutrient requirements and fertilizer strategies for the development of legume-based pastures in dry tropical rangelands of Hainan Island, China. Nutrient requirements for pastures grown on sandy and red loam soils were established using soil tests and missing element experiments with 3 test legumes. An acute $P$ deficiency (<5 mg kg-1 Bray P) was detected by soil tests on sandy soils, but no deficiencies were found on loam soil. The exclusion of $P$ from a total fertilizer treatment reduced relative yield to $20 \%$ of potential on sandy soil. A factorial $P$ rates experiment replicated in space and time showed a strong curvilinear response for stylo (Stylosanthes hamata L. Taub. cv. Verano) and siratro (Macroptilium atropurpureum (DC.) Urban) based pastures on sandy soil. No response was observed on loam soil. Given limited superphosphate supplies available for range improvement in south China, results from these studies showed no benefit from applying $P$ fertilizer to stylo pastures grown on soils with available $P>20 \mathrm{mg} \mathrm{kg}^{-1}$. In contrast, application of $P$ fertilizer proved both profitable and essential for development of legume-based pastures on P-deficient sandy soils. It is recommended that a rate of about $40 \mathrm{~kg}$ of $\mathrm{P} \mathrm{ha}^{-1}$ should be applied at establishment of stylo pastures on sandy soil. At this rate both legume yield and $P$ content of tops should be maintained at levels needed to sustain a beef production enterprise and return about $\mathbf{\$ 1 . 5}$ per dollar invested in fertilizer.
\end{abstract}

Key Words: China, dry tropical, Stylosanthes, Macroptilium, superphosphate, $\mathbf{P}$ response

Insufficient phosphorus and/or nitrogen are important constraints to pasture production in dry tropical regions. Where soils are P-deficient, the introduction of adapted legumes such as stylos (Stylosanthes spp.) which improve forage quality and provide

\footnotetext{
The authors wish to thank Huang Zhen-Sheng, former manager of Gaopoling Farm, for providing facilities for the experimental program and the Pasture Production Team for assisting with the field work. The vital communication link provided by interpreters Deng Zhou-Lien and Yen Ren-Chang between Australian advisers and their Chinese counterparts is gratefully acknowledged. DLM also thanks other members of the Australian team at Gaopoling Farm, Dr. J.F. Ayres and Mr. S.E. Dunn, and NSW Agriculture Overseas Project Director, Mr. G.D. Slennett, for their support and encouragement. The work was conducted under the auspices of the NSW-Guangdong Sister Government Agreement. The statistical advice provided by Ms. H. Nicol is also gratefully acknowledged.

Manuscript accepted 27 Feb. 1997.
}

nitrogen to the system offers most hope for sustained increase in animal production. The ability of stylos to grow on low $P$ soils is associated with a low internal requirement for optimum growth and/or a high capacity to absorb $\mathrm{P}$ at low levels of supply. Stylos are now used to improve low $P$ rangelands in many countries of the world's tropical regions, including China (Hong 1985; Michalk et al. 1993a).

However, while stylos can produce yield $>1.5 \mathrm{t} \mathrm{DM} \mathrm{ha}^{-1}$ on low P soil (Probert and Williams 1986; Winter et al. 1989a), the $P$ content of unfertilized stylo pastures is often well below the $P$ requirement of beef cattle (Probert and Williams 1986) which restricts liveweight performance (Winks et al. 1974). Legume content and $P$ concentration in forage can be increased significantly with inputs of $P$ fertilizer so that sustainable stocking rate and cattle liveweight gains are often double that of unfertilized stylo-grass pastures (Winter et al. 1989a, 1989b). Research has recommended initial dressings of superphosphate as high as 500 $\mathrm{kg} \mathrm{ha}^{-1}$ together with annual inputs of $250 \mathrm{~kg} \mathrm{ha}^{-1}$ to maintain stylo-based pastures in ideal condition. Despite good response to these rates, increases in fertilizer costs and declines in beef prices have meant that only small rates $\left(<10 \mathrm{~kg} \mathrm{P} \mathrm{ha}^{-1}\right)$ of superphosphate are irregularly applied to commercial pastures with the consequence that stylo pastures are growing below potential in dry tropical environments (Hall 1993). These economic pressures have led to a reassessment of the rationale for application of superphosphate to legume-based pastures in the tropics and the development of the concept of "low input" technology.

Low input soil management is based on 3 main principles (1) adaptation of plants to the soils constraints rather than elimination of all soil constraints to meet the requirement of less adapted plants; (2) maximization rather than optimization of output per unit of added fertilizer input; and (3) advantageous use of favourable attributes of infertile soils (eg. acidity, low effective cation exchange capacity) in formulating fertilizer strategies (Sanchez and Salinas 1981).

In south China, 40 million hectares of tropical and subtropical rangelands offer significant potential for red meat production (Hong 1985) provided suitable legumes are found to improve productivity and quality of range vegetation using low input systems. Previous papers in this series have examined the potential of legumes (Michalk et al. 1993a) and grasses (Michalk et al. $1993 \mathrm{~b})$ to improve dry tropical rangelands of Hainan Island. These studies recommended that a mixture of Stylosanthes scabra Vog. (cv. Seca) and S. hamata (L.) Taub. (cv. Verano) be used to improve low-P sandy areas, and Macroptilium atropuroureum (DC.) Urban. (siratro) be sown as a companion to 
Setaria sphacelate (Schum) Stapf ex Massey (cv. Kazungula) on moderate $\mathrm{P}$ red loam soils. However, given the widespread P deficiency in Chinese rangelands soils (Jiang et al. 1981) and the inadequacy of superphosphate supplies to meet demands for crops and pastures, it is unlikely that legume-based range improvement will be successful in south China unless low input fertilizer strategies are developed to sustain legume productivity and ensure adequacy of $\mathbf{P}$ for cattle growth.

In this third paper of a series which focuses on improvement of dry tropical rangelands in China, we report results of a 3 year (1981-1983) experimental program undertaken to assess the initial fertilizer requirements of sown pastures on low- and moderate-P soils at Gaopoling Model Cattle Farm (Dong Fang County) in western Hainan Island, People's Republic of China. The specific aims of the study were: (1) to identify nutrients deficient for legume growth based on soil tests; (2) to confirm nutrient deficiencies identified by soil tests by missing element study (Experiment 1); (3) to define response of adapted legumes to initial fertilizer application (Experiment 2); and (4) to measure the residual effect of fertilizer over 3 seasons (Experiment 2 ).

\section{Material and Methods}

\section{Site Description}

The experiments were conducted at Gaopoling Model Cattle Farm $\left(19^{\circ} 09^{\prime} \mathrm{N} ; 108^{\circ} 68^{\prime} \mathrm{W}\right)$ which is located in Dong Fang County on the western coast of Hainan Island, People's Republic of China. Annual rainfall for this dry tropical region averages $1,001 \mathrm{~mm}$ with $85 \%$ received in the mid-May to mid-October period. The vegetation is defined as a savanna with Heteropogon contortus (L.) Beauv. ex Roem. \& Schult, Aristida chinensis Munro. and Eragrostis elongata Jacq. as dominant grasses (Hu et al. 1992) in the interspaces between a range of scrubs (Michalk et al. 1993a) and a few trees. Few legumes are found in undisturbed grasslands, but with heavy grazing there is a steady increase with Alysicarpus vaginalis (L.) DC., Indigofera hirsuta L., and Desmodium triflorum (L.) DC. being the most important. More details of the location, climate, soil types, and unimproved range vegetation are given by Michalk et al. (1993a).

\section{Soil Types}

The soils on the site range from deep siliceous sands on the coastal plain to red loams in the undulating hinterland. Two main soil types (viz. sand and red loam) which differ in natural fertility were selected for the 2 experiments reported so that fertilizer recommendations could be formulated for the majority of the area set aside under new policies for rangeland improvement of Hainan Island. A sandy site which had been cropped previously with sweet potatoes, but at the time of study had reverted to poor quality degraded grassland was selected as representative of the large area of low P soils found in coastal rangelands of dry tropical Hainan. An area of red loam soil newly cleared of soft wood scrub was chosen as typical of the moderately fertile soils available for range improvement in the hinterland. These soils are mapped as "dry red earths" in the Chinese classification system which equates with Usttorroxs in Soil Taxonomy (Zhao and Shi 1986). Before site preparation was commenced, soil tests were conducted to confirm the fertility of both soils. Chemical properties $(0-10 \mathrm{~cm}$ samples) of both soils and critical nutrient levels for legume production are given in Table 1.
Table. 1. Plant nutrient levels of soils at Gaopoling Farm, Hainan Island.

\begin{tabular}{lccr}
\hline \hline Nutrient & $\begin{array}{c}\text { 90\% Critical } \\
\text { level }\left(\mathrm{mg} \mathrm{kg}^{-1}\right)\end{array}$ & $\begin{array}{c}\text { Soil type } \\
\text { Sand }\end{array}$ & Loam \\
\hline Phosphorus & $25^{1}$ & 3 & 20 \\
Potassium & 120 & 80 & 145 \\
Sulphur & 5 & 5 & 5 \\
Calcium & 500 & 480 & 1,828 \\
Magnesium & 50 & 88 & 296 \\
Iron & 5 & 18 & 32 \\
Copper & 0.3 & 0.1 & 0.3 \\
Zinc & 0.3 & 1.1 & 1.2 \\
Manganese & 100 & 68 & 136 \\
Molybdenum & 0.1 & $<0.1$ & $<0.1$ \\
Boron & 0.7 & na & 0.2 \\
Cobalt & $?$ & na & 0.4 \\
\hline
\end{tabular}

${ }^{1}$ Indicates critical levels for siratro; Underlined critical levels indicate toxicity level.

\section{Procedures}

\section{Experiment 1}

A missing element design with 14 treatments (Table 2) and 2 replications was used in Experiment 1 to determine the relative importance of nutrient deficiencies on each soil type identified by soil tests for growth of the 3 test legumes $M$. atropurpureum (Siratro), M. lathyroides (L.) Urban. (phasey bean cv Murray), and $S$. hamata (Carribean stylo cv. Verano) sown at 6, 10, and 12 $\mathrm{kg} \mathrm{ha}^{-1}$, respectively. Rate and form of nutrients used in each treatment are given in Table 2.

Table 2. Treatments, rates of nutrients, applied and chemical composition of nutrients used in Experiment 1.

\begin{tabular}{|c|c|c|}
\hline Treatment & \multicolumn{2}{|c|}{ Nutrients included } \\
\hline Control 1 & \multicolumn{2}{|c|}{ No nutrients applied } \\
\hline Control 2 & \multicolumn{2}{|c|}{$\begin{array}{l}\text { All nutrients applied (P, K, S, Mg, Cu, Zn, Mo, Co, } \\
\mathrm{Fe}, \mathrm{Mn}, \mathrm{B}, \text { Lime 1) }\end{array}$} \\
\hline Phosphorus & \multicolumn{2}{|c|}{ All nutrients except $P$} \\
\hline Potassium & “ & $\mathbf{K}$ \\
\hline Sulphur & “ & $S$ \\
\hline Magnesium & 4 & $\mathbf{M g}$ \\
\hline Copper & “ & $\mathrm{Cu}$ \\
\hline Zinc & 4 & $\mathrm{Zn}$ \\
\hline Molybdenum & “ & Mo \\
\hline Cobalt & “ & Co \\
\hline Iron & “ & $\mathrm{Fe}$. \\
\hline Manganese \& Boron. & “ & Mn \& B \\
\hline Lime 1 & “ & Lime at $250 \mathrm{~kg} \mathrm{ha}^{-1}$ \\
\hline Lime 2 (Increase $\mathrm{pH}$ ) & “ & plus Lime at $4,000 \mathrm{~kg} \mathrm{ha}^{-1}$ \\
\hline
\end{tabular}

\begin{tabular}{llc}
\hline Nutrient & Form of nutrient & $\begin{array}{c}\text { Application rate } \\
\left.\text { (kg nutrient ha }{ }^{-1}\right)\end{array}$ \\
\hline Phosphorus & $\mathrm{NaH}_{2} \mathrm{PO}_{4}$ & 50 \\
Potassium & $\mathrm{KCl}$ & 50 \\
Sulphur & $\mathrm{Elemental} \mathrm{S}$ & 25 \\
Magnesium & $\mathrm{MgO}$ & 25 \\
Copper & $\mathrm{CuSO}_{4}$ & 4 \\
Zinc & $\mathrm{ZnSO}_{4}$ & 4 \\
Molybdenum & $\mathrm{MoO}_{3}$ & 0.5 \\
Cobalt & $\mathrm{CoCl}_{2}$ & 1 \\
Iron & $\mathrm{Fe}_{2}\left(\mathrm{SO}_{4}\right)_{3}$ & 4 \\
Manganese & $\mathrm{MnSO}_{4}$ & 1 \\
Boron & $\mathrm{H}_{3} \mathrm{BO}_{3}$ & 1 \\
Lime 1 & $\mathrm{CaCO}_{3}$ & 250 \\
Lime 2 & $\mathrm{CaCO}_{3}$ & 4,000 \\
\hline
\end{tabular}


Pre-weighed nutrients were mixed with dry soil taken from each $2 \times 10-\mathrm{m}$ plot, broadcast with inoculated legume seed, and lightly raked. Treatment plots were separated by 2-m buffers to prevent nutrient movement between treatments. Forage harvested from 4 randomly selected $0.25 \mathrm{~m}^{2}$ quadrats/plot in early November (end of wet season) was sorted and dried to assess dry matter yield and botanical composition.

Legume production (averaged over test legumes) in plots fertilized with complete nutrient treatment (Control 2) was compared with yield measured in unfertilized plots (Control 1) and a series of treatments in which each nutrient was excluded, in turn, from Control 2 (Table 2). For ease of analysis and interpretation, legume production was expressed as yield relative to Control 2 . If relative yield of a treatment was $<40 \%$ of Control 2, the missing element was considered to be seriously deficient, but if relative yield was $>80 \%$ of Control 2 , availability of that nutrient was reckoned to be adequate for legume growth. Marginal deficiencies were defined between these limits. Relative yields were analysed by a factorial analysis of variance with 14 fertilizer treatments and 3 species as main effects.

\section{Experiment 2}

A split-plot design with 3 replications of 5 rates of phosphorus $\left(0,7,14,28\right.$, and $\left.56 \mathrm{~kg} \mathrm{ha}^{-1}\right)$ applied as superphosphate at planting to main plots was used to define $P$ responses of a P-efficient (Verano stylo) and P-inefficient (Siratro) legumes. Analysis showed that Chinese Grade 4 superphosphate contained $9.3 \% \mathrm{P}$, $1.5 \% \mathrm{~K}, 12.1 \% \mathrm{~S}$, and $18 \% \mathrm{Ca}$. The experiment was replicated in time with sequential plantings on 27 July 1981, 28 June 1982, and 27 July 1983 on both soil types. For all plantings, legume seed was scarified using hot water, dried, inoculated, pelleted with rock phosphate, and sown by hand at $8 \mathrm{~kg} \mathrm{ha}^{-1}$ with the appropriate amount of pre-wcighed supcrphosphate.

Establishment and persistence were measured by counts of sown species made in November in the establishment year, and again in July and November of years 2 and 3 (if applicable) of each sowing in 4 randomly placed $0.5 \times 0.5-\mathrm{m}$ quadrats in each treatment plot. Yield and botanical composition were determined as described for Experiment 1. The management program for this study was to graze plots at the end of the dry season after yield assessment to remove mature pasture; no grazing was undertaken during the growing season. Dried sub-samples ground in a benchtop grinder were analysed for $P$ and $N$ content for the 1981 sowing only. To monitor soil $\mathrm{P}$, four $10-\mathrm{cm}$ diameter augur samples were collected from the $0-10$ and $10-20-\mathrm{cm}$ layers in each subplot of the 1981 sowing, combined with other replicates, and a 500-g sub-sample taken for analysis.

Split-plot analyses of variance were set up in a Genstat program (Payne et al. 1988) to analyze density and yield data for establishment year performance of each species sown in the 3 sequential sowings with 2 soil types and 3 establishment years as main effects. Linear and non-linear regressions were used to examine relationships between yield and applied $P$. The linear response and plateau (LRP) model which is independent of costs and prices (Sanchez 1976) was used to determine optimum P fertilizer required to sustain pastures for a 3-year period.

\section{Results}

\section{Soil Tests}

Large differences in native fertility were observed between soils (Table 1). The sand was the most infertile with acute deficiencies of $P$ and $K$, marginal deficiencies of $\mathrm{Cu}$ and possibly Mo for production of sown legumes. With levels below $15 \mathrm{mg} \mathrm{kg}^{-1}$ (Bray test), $\mathrm{P}$ is the most limiting nutrient for legume growth. Although $\mathrm{Ca}$ is low in sandy soil (Table 1), it still accounts for more than $50 \%$ of the cation exchange capacity (Michalk et al. 1993a). In contrast, the loam soil was moderately fertile with adequate levels of all nutrients for legume growth. However, the high Mn level may affect production of Mn-sensitive legumes such as Leucaena leucocephala (Lam.) De Wit. With $\mathrm{pH}$ values above 5.0 in surface horizons (Michalk et al. 1993a), exchangeable $\mathrm{Al}$ is low, and there is no danger of aluminum toxicity affecting plant growth in these soils.

\section{Experiment 1}

Test legumes established well with similar densities measured on both soil types. However, soil type affected yield of trailing legumes with the siratro and phasey bean producing 4 to 6 times more dry matter on loam soil than sand when supplied with a complete fertilizer (Table 3). Yield of Verano stylo which was greatest on sandy soil was not affected by soil type. Although yields differed between legumes $(P<0.05)$, the relative response to the omission of various nutrients was similar. Fertilizer treatments did not affect yield of volunteer native grasses.

On sandy soil, relative yield of legume averaged over the 3 test species was significantly reduced to $20 \%$ of Control 2 when P fertilizer was not applied (Table 3). The similarity in relative

Table 3. Yields (relative to Control 2) of test species sown in missing element studies on some soil types at Gaopoling Farm.

\begin{tabular}{|c|c|c|}
\hline \multirow[t]{2}{*}{ Treatment } & \multicolumn{2}{|c|}{ Soil type 0} \\
\hline & Sand & Loam \\
\hline \multicolumn{3}{|c|}{$\begin{array}{l}\text { Yield (kg DM legume ha }{ }^{-1} \text { ) } \\
\text { Control } 2^{1}\end{array}$} \\
\hline Verano stylo & $1,462 \mathrm{c}$ & $1,378 \mathrm{c}$ \\
\hline Phasey bean & $1,235 \mathrm{c}$ & 7,821 a \\
\hline Siratro & $775 \mathrm{~d}$ & $3,207 b$ \\
\hline \multicolumn{3}{|l|}{ Relative yield (\%) } \\
\hline Control $1^{2}$ & $16 *$ & 85 \\
\hline Control 2 & 100 & 100 \\
\hline$-\mathbf{P}$ & $20 *$ & 91 \\
\hline$-\mathbf{K}$ & 97 & 125 \\
\hline$-\mathbf{S}$ & 90 & 85 \\
\hline$-\mathbf{M g}$ & 96 & 96 \\
\hline$-\mathrm{Cu}$ & 83 & 102 \\
\hline$-\mathbf{Z n}$ & 119 & 96 \\
\hline- Mo & 76 & 109 \\
\hline$-\mathrm{Co}$ & 79 & 109 \\
\hline$-\mathrm{Fe}$ & 86 & 96 \\
\hline$-\mathbf{M n} \& \mathrm{~B}$ & 103 & 76 \\
\hline + Lime 1 & 109 & 93 \\
\hline + Lime 2 & 96 & 75 \\
\hline $\operatorname{Isd}_{(5 \%)}$ & 31 & 39 \\
\hline
\end{tabular}


yield between unfertilized control (Control 1) and the P-minus treatment confirmed that insufficient $P$ was the main constraint to legume growth. With the possible exception of Mo, legume growth was not affected by omission of any other nutrient identified by soil tests as being marginally deficient on sandy soil (Table 1).

On loam soil, relative yield was slightly reduced by exclusion of $\mathrm{Mn}$ and $\mathrm{B}$, and when lime was applied to induce $\mathrm{pH}$ change (Table 3) of soil. Since the native level of soil Mn exceeded the critical level for legumes (Table 1), this reduction in relative yield indicates a marginal B deficiency as lime application would also reduce $B$ availability. The omission experiment showed that loam soil supplied all other nutrients in amounts sufficient for growth of the test legumes.

\section{Experiment 2 \\ Establishment Year Yield Response}

Soil type and year of sowing affected $(P<0.05)$ production of both test legumes in 1-year-old swards (Fig. 1). Siratro yielded best on loam, especially in 1981 where production averaged $>3.5$ $\mathrm{t} \mathrm{DM} \mathrm{ha}^{-1}$ in all $\mathrm{P}$ treatments which was at least 5 times the yield measured on sandy soil. Low siratro yield $\left(<1.0 \mathrm{tha}^{-1}\right)$ in 1982 was caused by a protracted period of moisture stress (late July to early September) shortly after sowing which killed many siratro seedlings. Growth of the more drought hardy Verano stylo which performed best on sandy soil but also established vigorous stands on loam soil (Fig. 1), was enhanced by this mini-drought which reduced competition from volunteer grasses and forbs. Excessive leaching of nutrients coupled with seed damage and removal caused by $417 \mathrm{~mm}$ of rainfall received in a 24-hour period 2 weeks after sowing may explain in part the poor performance of both legumes in the 1983 sowing.
Siratro did not respond to applied P on either soil type (Fig. 1). Similarly, Verano stylo sown on loam soil did not respond to applied $P$ in 1981 and 1983, and only a slight response was measured in the 1982 sowing. However, on sandy soil application of $P$ increased $(P<0.05)$ establishment year yield of verano in 1981 and 1982 sowings with the last 28 units of applied $P$ still producing a response of 44 and $66 \mathrm{~kg} \mathrm{DM} \mathrm{kg}^{-1}$ of P (Fig. 1). Poor establishment in 1983 affected the ability of Verano to respond to $\mathrm{P}$.

Companion species in siratro plots sown on sandy soil responded $(\mathrm{P}<0.05)$ to $\mathrm{P}$ with the $\mathrm{P} 56$ treatments producing more than twice as much as the control in each of the 3 sowings (Fig. 1). In contrast, the "companion species" component of verano plots was not affected by $P$ rate. Year of sowing also affected growth of volunteer grasses and forbs on the sandy soil with yields in 1981 exceeding $(\mathrm{P}<0.05)$ those measured in 1982 and 1983. Companion species did not respond to $\mathrm{P}$ on loam soil during the establishment phase of both legumes and only a small effect of year of sowing with greater yield in 1983 compared to 1981 and 1982 (Fig. 1).

\section{Second, Third and Total Yield}

Yield responses of 2- and 3-year-old pastures to applied $P$ are shown in Table 4 together with mean establishment year (1-yearold) production of siratro and verano swards on the 2 soil types. Verano was the most productive legume on both soils with an accumulated 3-year total of 8 and $6 \mathrm{tha}^{-1}$ for sand and loam soils, respectively, at the P56 rate. This was more than twice the yield of siratro on sandy soil and $30 \%$ higher than siratro production on loam soil.

Difference in verano yield due to soil type resulted from higher production in 1-year-old and 3-year-old swards on sandy soil at the higher P levels (Fig. 1; Table 4). Although verano responded

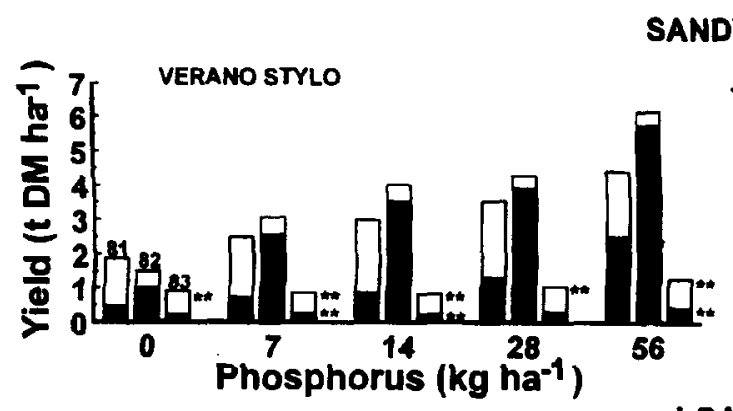

SANDY SOIL
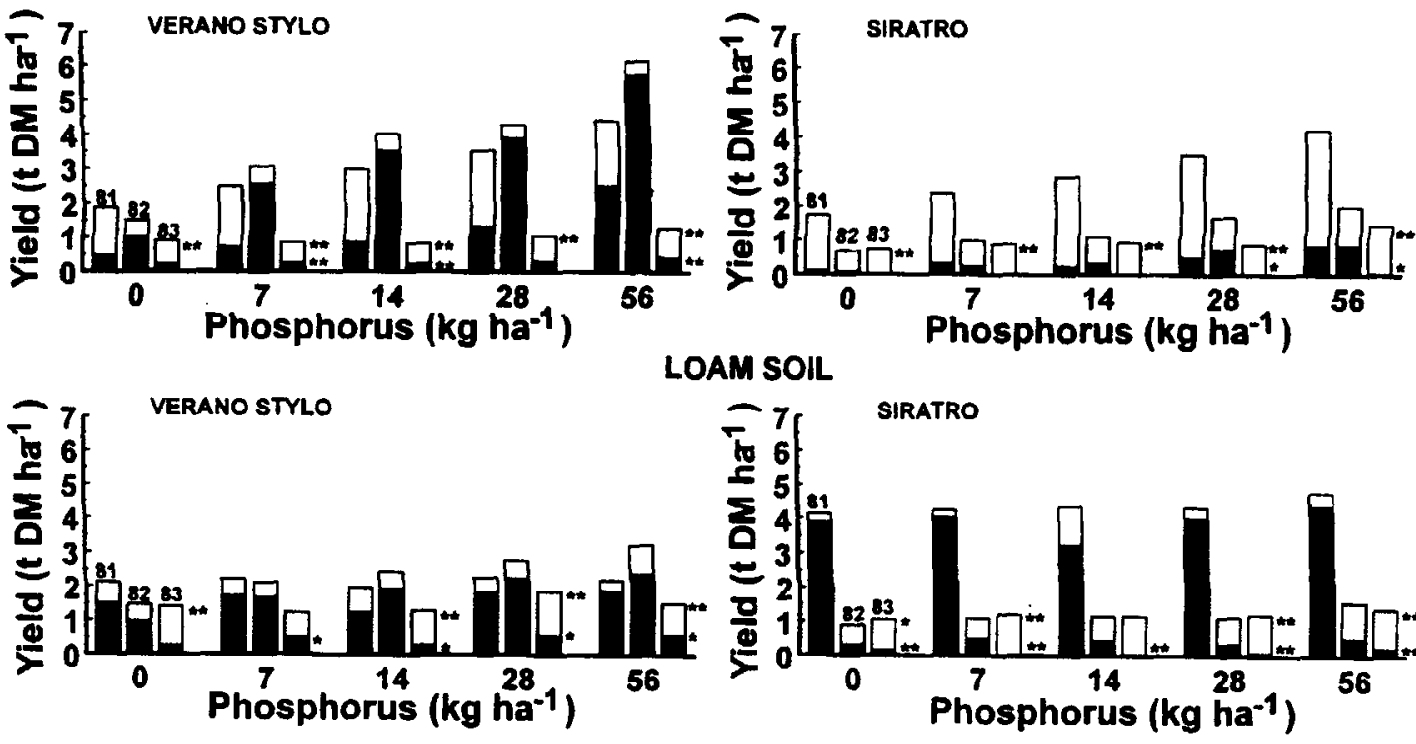

LOAM SOIL
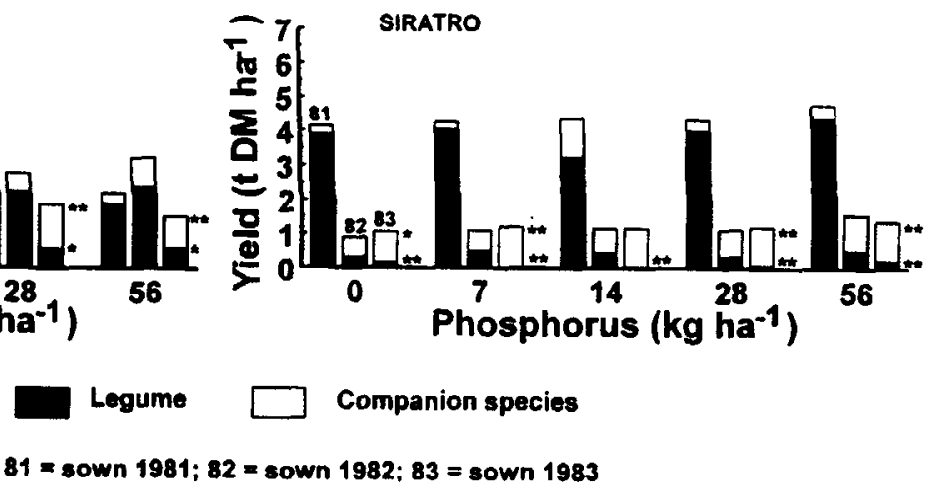

Fig. 1. Establishent year production for verano stylo and siratro sown on sand and loam soils with a range of phosphorus rates applied as superphosphate at Gaopoling Farm. Note * and ** indicate significant differences in legume or other species yields due to $P$ fertilizer within soil types and sown legume treatments at $P<0.05$ and $P<0.01$. 
Table 4. Yield of legume and "other species" in 1-, 2-, and 3-year-old Verano and siratro pastures sown on sand and loam soil with a range of $P$ rates at Gaopoling Farm (1981-1983).

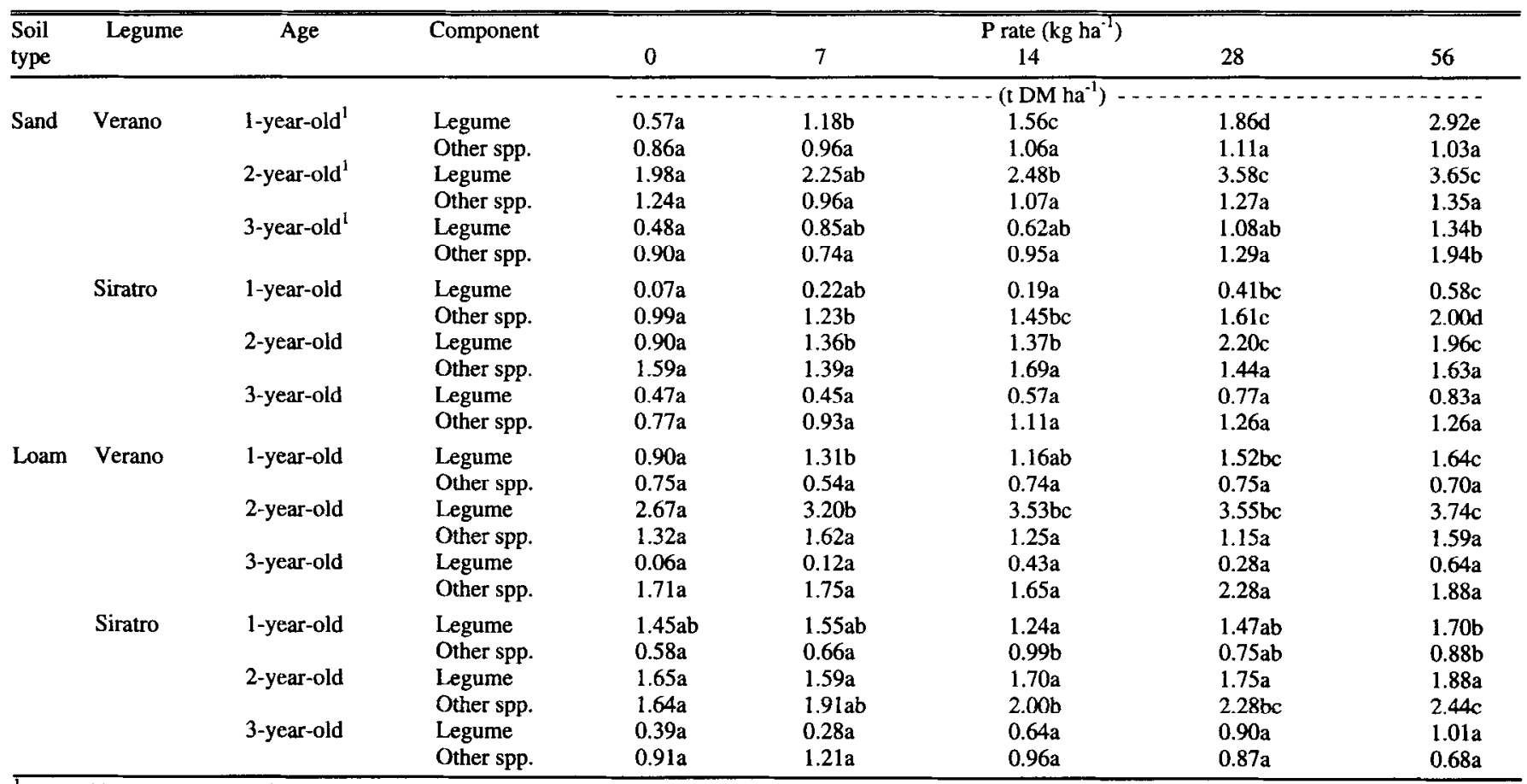

${ }^{1} 1$-year-old production mean of sequential sowings in 1981, 1982, and 1983. 2-year-uld production mean of 1981 sowing cut in 1982 and 1982 sowing cut in 1983. 3-year-old production is 1981 sowing cut in $1983 .{ }^{2}$ Yields within soil types, sown legume type, age, and pasture component followed by the same letter are not significantly different at $P<0.05$.

$(P<0.05)$ to applied $P$ on both soils, the effect was greater on sandy soil with significant yield increases in 2-year-old and 3year-old pastures. Siratro yield was only increased $(P<0.05)$ by $P$ application in 2-year-old pastures on sandy soil.

The effect of initial $P$ application on yield of both legumes declined over time with 3 -year-old pastures yielding less $(\mathrm{P}<0.05)$ than 2-year-old pastures at all $P$ rates on both soil types. On sandy soil this was due to a decline in the available soil $P$ level and low $P$ content of top growth (see below), but on loam soil a wildfire which burned the 1981 site in late August, 1983 was the cause of low production in 3-year-old swards. Production loss for verano predicted from logarithmic equations fitted to production data for 1- and 2-year-old swards on loam soil ranged from $3 \mathrm{t} \mathrm{ha}^{-1}$ for PO to $4.3 \mathrm{t} \mathrm{ha}^{-1}$ for P56. For siratro, however, the yield loss due to fire was estimated to be $<0.6 \mathrm{tha}^{-1}$

Rate of $P$ rate did not affect yield of companion grasses and forbs in 2-year-old and 3-year-old siratro swards on sandy soil or in 1-year-old or 2-year-old verano plots, but a significant yield increase of "other species" was measured in P56 treatment of 3year-old verano plots (Table 4 ). On loam soil, $P$ rate had no effect
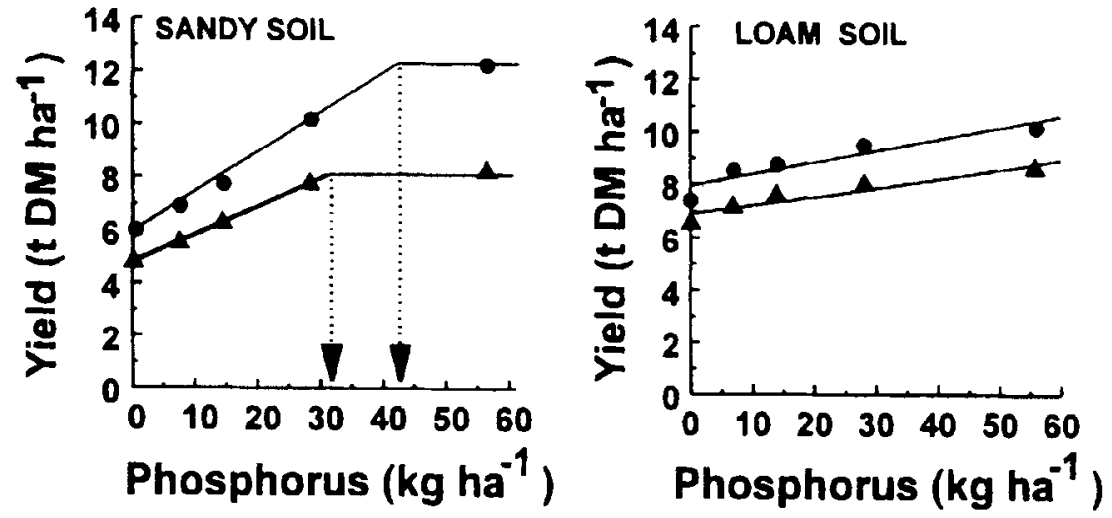

- Verano A Siratro

Fig. 2. Production (sown legume + other species) totalled for 1-, 2-, and 3-year-old verano and siratro pastures sown on sandy and loam soils with a range of $P$ rates of Gaopoling Farm. 
Table 5. $P$ and $N$ content of verano, siratro, and volunteer species fertilized with different rates of superphosphate applied to sand and loam soils in 1981.

\begin{tabular}{|c|c|c|c|c|c|c|}
\hline \multirow{3}{*}{$\begin{array}{l}\text { Fertilizer } \\
\text { rate } \\
\left(\mathrm{kg} \mathrm{P} \mathrm{ha}^{-1}\right)\end{array}$} & \multicolumn{6}{|c|}{ Year } \\
\hline & \multicolumn{2}{|c|}{1981} & \multicolumn{2}{|c|}{1982} & \multicolumn{2}{|c|}{1983} \\
\hline & Legume & Grass & Legume & Grass & Legume & Grass \\
\hline \multicolumn{7}{|c|}{ Phosphorus (\%) } \\
\hline \multicolumn{7}{|c|}{ Verano stylo } \\
\hline 0 & 0.10 & 0.12 & 0.10 & 0.11 & 0.09 & 0.08 \\
\hline 7 & 0.17 & 0.16 & 0.11 & 0.14 & 0.09 & 0.10 \\
\hline 14 & 0.19 & 0.16 & 0.13 & 0.13 & 0.11 & 0.11 \\
\hline 28 & 0.25 & 0.21 & 0.13 & 0.13 & 0.12 & 0.11 \\
\hline 56 & 0.24 & 0.29 & 0.17 & 0.21 & 0.13 & 0.12 \\
\hline \multicolumn{7}{|l|}{ Loam soil } \\
\hline 0 & 0.15 & 0.21 & 0.14 & 0.17 & 0.14 & 0.14 \\
\hline 7 & 0.16 & 0.21 & 0.14 & 0.22 & 0.14 & 0.16 \\
\hline 14 & 0.14 & 0.22 & 0.15 & 0.17 & 0.15 & 0.16 \\
\hline 28 & 0.17 & 0.19 & 0.14 & 0.24 & 0.15 & 0.16 \\
\hline 56 & 0.19 & 0.27 & 0.16 & 0.24 & 0.15 & 0.21 \\
\hline \multirow{2}{*}{\multicolumn{7}{|c|}{$\begin{array}{l}\text { Siratro } \\
\text { Sandy soil }\end{array}$}} \\
\hline & & & & & & \\
\hline 0 & 0.10 & 0.11 & 0.11 & 0.09 & 0.09 & 0.10 \\
\hline 7 & 0.14 & 0.15 & 0.14 & 0.10 & 0.09 & 0.12 \\
\hline 14 & 0.17 & 0.19 & 0.14 & 0.10 & 0.10 & 0.10 \\
\hline 28 & 0.18 & 0.20 & 0.15 & 0.10 & 0.09 & 0.11 \\
\hline 56 & 0.20 & 0.22 & 0.16 & 0.10 & 0.11 & 0.11 \\
\hline \multicolumn{7}{|l|}{ Loam soil } \\
\hline 0 & 0.32 & 0.22 & 0.24 & 0.20 & 0.16 & 0.15 \\
\hline 7 & 0.32 & 0.19 & 0.26 & 0.19 & 0.17 & 0.15 \\
\hline 14 & 0.32 & 0.24 & 0.27 & 0.23 & 0.18 & 0.14 \\
\hline 28 & 0.35 & 0.25 & 0.29 & 0.23 & 0.20 & 0.16 \\
\hline 56 & 0.38 & 0.27 & 0.37 & 0.24 & 0.26 & 0.20 \\
\hline \multicolumn{7}{|c|}{ Nitrogen (\%) } \\
\hline \multirow{2}{*}{\multicolumn{7}{|c|}{$\begin{array}{l}\text { Verano stylo } \\
\text { Sandy soil }\end{array}$}} \\
\hline & & & & & & \\
\hline 0 & 1.88 & 1.77 & 1.74 & 1.53 & 1.88 & 1.25 \\
\hline 7 & 1.98 & 1.43 & 1.92 & 1.30 & 1.94 & 1.26 \\
\hline 14 & 1.92 & 1.00 & 2.79 & 1.49 & 1.67 & 1.20 \\
\hline 28 & 1.93 & 1.42 & 3.06 & 1.67 & 2.02 & 1.14 \\
\hline 56 & 2.46 & 1.66 & 2.88 & 2.21 & 2.02 & 1.49 \\
\hline \multicolumn{7}{|l|}{ Loam soil } \\
\hline 0 & 1.57 & 1.05 & 1.68 & 1.04 & 1.44 & 0.94 \\
\hline 7 & 1.76 & 1.05 & 2.15 & 1.06 & 1.41 & 0.99 \\
\hline 14 & 1.63 & 0.93 & 1.79 & 1.02 & 1.57 & 0.85 \\
\hline 28 & 1.76 & 1.14 & 1.81 & 1.23 & 1.72 & 1.25 \\
\hline 56 & 2.05 & 1.61 & 2.03 & 1.18 & 2.13 & 1.32 \\
\hline \multicolumn{7}{|l|}{ Siratro } \\
\hline \multicolumn{7}{|l|}{ Sandy soil } \\
\hline 0 & 1.80 & 1.34 & 2.05 & 1.09 & 1.92 & 1.17 \\
\hline 7 & 1.81 & 1.33 & 2.03 & 1.10 & 1.81 & 1.24 \\
\hline 14 & 1.93 & 1.33 & 2.04 & 1.32 & 1.92 & 0.99 \\
\hline 28 & 1.90 & 1.33 & 2.04 & 1.28 & 1.87 & 0.89 \\
\hline 56 & 1.85 & 1.30 & 1.77 & 1.14 & 2.10 & 1.21 \\
\hline \multicolumn{7}{|l|}{ Loam Soil } \\
\hline 0 & 2.41 & 0.89 & 1.96 & 0.84 & 1.62 & 0.93 \\
\hline 7 & 2.13 & 0.93 & 2.22 & 0.86 & 1.71 & 0.78 \\
\hline 14 & 2.42 & 1.10 & 2.24 & 1.03 & 1.82 & 0.84 \\
\hline 28 & 2.18 & 1.00 & 2.18 & 0.85 & 1.93 & 0.86 \\
\hline 56 & 2.26 & 1.29 & 2.26 & 0.96 & 1.97 & 1.00 \\
\hline
\end{tabular}

on the yield of companion species in verano plots, but did increase the grass component in siratro plots fertilized with $\mathbf{P}$ rates $>14 \mathrm{~kg} / \mathrm{ha}$.

Production (legume + "companion species") totalled for 1year-old, 2-year-old, and 3-year-old verano swards exceeded that of siratro on both soils and at all $P$ rates (Fig. 2). $P$ rate increased the contribution of verano from 50 to $>60 \%$ on both soils. For siratro significant interaction occurred between soil type and $\mathrm{P}$ rate with higher production on loam soil at all $\mathrm{P}$ rates except P56. A difference also occurred in pasture composition with a higher proportion of siratro present on loam soil $(>50 \%$ in all treatments), and a significant increase in legume contribution on sandy soil due to $\mathrm{P}$ application ( $30 \%$ at $\mathrm{P0}$ to $41 \%$ at P56).

\section{Plant Nutrient Concentrations}

Phosphorus: $\mathrm{P}$ concentration in top-growth of verano and siratro grown on unfertilized sand were $0.10 \%$ and $0.11 \%$ or less, respectively (Table 5), which are below the critical values for these legumes $(0.17 \%$ and $0.24 \%$, respectively). On unfertilized loam, $\mathrm{P}$ content of siratro tops ranged from $0.32 \%$ in 1981 to $0.16 \%$ measured in 3-year-old swards in 1983, whereas the $P$ content of Verano remained static on loam soil over the 3 years (Table 5).

Application of $\mathbf{P}$ fertilizer increased $\mathbf{P}$ content of verano tops initially to $0.24 \%$ in the P56 treatment on sandy soil, but declined to $0.13 \%$ after 3 years. A similar pattern was evident for siratro on sandy soil, but unlike verano, the $P$ content of siratro did not reach the critical value at any time of fertilizer rate on sandy soil (Table 5). On loam soil, however, the P content of siratro was maintained about the critical level in all treatments until 1983 when only the P56 plots had P contents $>0.24 \%$.

On both soils, verano yield increased linearly with increasing $P$ content of tops, although this only reached significance $(P<0.05)$ on loam soil in the establishment year. A similar trend was evident for siratro, particularly on sand soil where $P$ content of tops explained more than $65 \%$ of yield variation in 1981 and 1982 (Tables 4 and 5).

$P$ content of companion species was significantly lower on sandy soil and only exceeded $0.20 \%$ (a generally accepted critical level for tropical grasses-Andrew and Robins 1971) when initial $P$ fertilizer exceeded $28 \mathrm{~kg} \mathrm{P} \mathrm{ha}^{-1}$ in the initial year (Table 5). Sown legumes did not consistently affect $P$ content of voluntecr grasses and forbs.

Nitrogen: $\mathbf{N}$ content of tops was positive correlated to yield of verano and siratro. For verano this was particularly evident on sandy soil $\left(R^{2}=0.70\right)$ where $\mathrm{N}$ content increased from $<2 \%$ with yield $<1 \mathrm{t} \mathrm{ha}^{-1}$ to $3 \%$ with yield $>4 \mathrm{t} \mathrm{ha}^{-1}$. In contrast, the relationship for siratro was significant $\left(R^{2}=0.64\right)$ only on loam soil where siratro yield was greater and $\mathrm{N}$ content increased from

Table 6. Effect on soil P (Bray test) of superphosphate applied in 1981 to sand and loam soils at Gaopoling Farm.

\begin{tabular}{|c|c|c|c|}
\hline \multirow{2}{*}{$\begin{array}{l}\text { Fertilizer } \\
\text { rate } \\
\left(\mathrm{kg} \mathrm{P} \mathrm{ha}^{-1}\right)\end{array}$} & \multicolumn{3}{|c|}{ Year } \\
\hline & $\begin{array}{c}1981 \\
\text { (May) }\end{array}$ & $\begin{array}{c}1982 \\
\text { (February) }\end{array}$ & $\begin{array}{c}1983 \\
\text { (February) }\end{array}$ \\
\hline & \multicolumn{3}{|c|}{ ( $\mathrm{mg} \mathrm{kg}^{-1}$ available $\mathrm{P}$ ) } \\
\hline \multicolumn{4}{|l|}{ Sand soil } \\
\hline 0 & $3^{1}$ & $2.7^{2}$ & 2.4 \\
\hline 7 & & 2.7 & 2.7 \\
\hline 14 & & 5.4 & 4.5 \\
\hline 28 & & 8.1 & 7.5 \\
\hline 56 & & 9.1 & 9.0 \\
\hline \multicolumn{4}{|l|}{ Loam soil } \\
\hline 0 & $20^{1}$ & $19.5^{2}$ & 17.6 \\
\hline 7 & & 29.9 & 25.5 \\
\hline 14 & & 31.6 & 25.7 \\
\hline 28 & & 31.9 & 27.7 \\
\hline 56 & & 30.9 & 30.4 \\
\hline
\end{tabular}

${ }^{1}$ Soil test prior to sowing; ${ }^{2}$ means for siratro and stylo plots. 
Table 7. Annual recovery of $P$ fertilizer by stylo- and siratro-based pastures expressed as a percentage of total fertilizer $P$ recovered over 3 years (1981-83) on sandy soil at Gaopoling Farm.

\begin{tabular}{|c|c|c|c|c|c|c|c|c|c|c|}
\hline \multirow{3}{*}{$\begin{array}{l}\text { Fertilizer } \\
\text { rate }\end{array}$} & \multirow{2}{*}{\multicolumn{2}{|c|}{$\begin{array}{c}\text { Total P } \\
\text { recovered }\end{array}$}} & \multirow{2}{*}{\multicolumn{2}{|c|}{$\begin{array}{l}\text { Fertilizer } P^{2} \\
\text { recovered }^{2}\end{array}$}} & \multicolumn{6}{|c|}{ Annual recovery } \\
\hline & & & & & & & & & & \\
\hline & Legume & Grass & Legume & Grass & Legume & Grass & Legume & Grass & Legume & Grass \\
\hline $\begin{array}{l}\left.\text { (kg } \mathbf{P} \text { ha }^{-1}\right) \\
\text { Verano-ba }\end{array}$ & \multicolumn{2}{|c|}{$\left(\mathrm{kg} \mathrm{P} \mathrm{ha}^{-1} 3\right.$ year $\left.^{-1}\right)$} & \multicolumn{2}{|c|}{$\left(\mathrm{kg} \mathrm{P} \mathrm{ha}^{-1} 3\right.$ year $\left.^{-1}\right)$} & \multicolumn{6}{|c|}{ 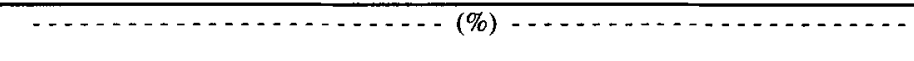 } \\
\hline 0 & 2.7 & 3.8 & & & & & & & & \\
\hline 7 & 4.3 & 5.2 & 1.6 & 1.4 & 43 & 78 & 31 & 14 & 25 & 7 \\
\hline 14 & 5.2 & 8.3 & 2.5 & 4.5 & 44 & 38 & 44 & 53 & 12 & 9 \\
\hline 28 & 10.2 & 7.6 & 7.5 & 3.8 & 37 & 79 & 51 & 3 & 12 & 18 \\
\hline 56 & 15.2 & 10.5 & 12.5 & 6.7 & 45 & 57 & 44 & 19 & 11 & 24 \\
\hline \multicolumn{11}{|c|}{ Siratro-based pasture } \\
\hline 0 & 2.2 & 4.4 & & & & & & & & \\
\hline 7 & 3.5 & 6.0 & 1.3 & 1.6 & 31 & 81 & 69 & 0 & 0 & 19 \\
\hline 14 & 3.7 & 8.3 & 1.5 & 3.9 & 20 & 82 & 67 & 10 & 13 & 8 \\
\hline 28 & 6.1 & 9.4 & 3.9 & 5.0 & 20 & 84 & 72 & 4 & 8 & 12 \\
\hline 56 & 6.7 & 10.7 & 4.5 & 6.3 & 33 & 90 & 56 & 0 & 11 & 10 \\
\hline
\end{tabular}

${ }^{1}$ Calculated by the product of $P$ content in tops (Table 5) and pasture yield for 1981 sowing; ${ }^{2}$ Calculated by subtracting amount of $P$ recovered at zero fertilizer from amounts recovered when fertilized.

$1.8 \%$ with yields $<1 \mathrm{t}$ /ha to $2.4 \%$ when yield exceeded $4 \mathrm{t} \mathrm{ha}^{-1}$. Yields of companion species were not consistently related to $\mathrm{N}$ content of tops on either soil or with either sown legume. P application consistently increased $\mathrm{N}$ concentrations in verano on both soil types, but had no effect on the $\mathrm{N}$ content of siratro (Table 5).

\section{Changes in Soil Phosphorus}

Verano and siratro plots were similar in Bray No $1 \mathrm{P}$ measured in the $0-10 \mathrm{~cm}$ soil depth, so only mean values for each $P$ treatment are given in Table 6. Levels were low in control (P0) plots on sandy soil throughout the experiment $\left(<3 \mathrm{mg} \mathrm{kg}^{-1}\right)$ and decreased slightly on loam soil. The addition of $14 \mathrm{~kg} \mathrm{P} \mathrm{ha}^{-1}$ doubled available P on sandy soil while the P56 treatment applied in 1981 maintained the $P$ level at $9 \mathrm{mg} \mathrm{kg}^{-1}$ until the end of the study. Applied $P$ increased available $P$ in loam soil by a similar factor and with similar residual to sandy soil.

\section{Recovery Rate of P Fertilizer}

Data from the 1981 sowing showed the amount of fertilizer $P$ recovered in the top growth of the verano- and siratro-based pastures with increasing fertilizer rates (Table 7). Total fertilizer $P$ recovered over the 3 years in plant tops ranged from $>38 \%$ for both pastures at low $\mathrm{P}$ rates to $34 \%$ for verano pastures and $19 \%$ for siratro pastures in the P56 treatments. While there was little difference in the amount of fertilizer $P$ recovered by the legume component at the 2 low fertilizer rates, verano stylo recovered 100 to $200 \%$ more P than siratro at P28 and P56. The recovery pattern was also different with verano recovering an equal amount of $P$ in 1981 and 1982, whereas siratro recovered more than two-thirds of its total $P$ in 1982. This was due to the slow rate at which siratro established leading to low DM yield in 1981 .

Overall, there was little difference in the amount of fertilizer $P$ recovered by companion grasses in the 2 pasture types when fertilizer was applied at the same rate of $P$. Most of this $P$ was recovered by grasses in the first year of application (Table 7), especially in siratro pastures where legume yield was low (Fig. 1).

\section{Optimum P Rates for Verano and Siratro}

For sandy soil, the LRP model set the optimum $P$ rate for verano and siratro at 43 and $32 \mathrm{~kg} \mathrm{ha}^{-1}$, respectively (Fig. 2). However, for loam soil, a high regression coefficient for linear functions over the entire $\mathbf{P}$ input range indicated that there was no clear optimum for either legume, and therefore $P$ fertilizer was not recommended for this soil type based on the pasture production observed in these studies.

\section{Discussion and Management Implications}

The experiments reported were conducted over 3 seasons of variable but adequate rainfall on pastures of varying age on the 2 most common soil types targeted for range improvement in western Hainan Island. Based on results of soil tests, missing element studies and pasture responses, it was concluded that $\mathrm{P}$ fertilizer must be applied to sandy soils for successful pasture development, but that legumes could be oversown on loam soil with little or no fertilizer.

\section{$P$ response on sandy soil}

Verano and siratro both established on these very P-deficient soils without superphosphate application, but yield and $\mathbf{P}$ content of tops were low, especially for siratro. Pasture production was significantly increased by applying $\mathbf{P}$ fertilizer with the response generally associated with the legume component rather than the companion grasses.

Siratro pastures: Overall there was a much lower yield response of siratro-based pastures to $P$ fertilizer than for verano. Although it is generally observed that siratro yield decreases as the yield of associated grasses increases. (Rees et al. 1976), our results showed that the performance of siratro was limited by its inability to obtain sufficient $P$ from these soils with low available P (even when fertilized), rather than from overtopping by companion grasses as reported elsewhere (e.g. Jones and Jones 1976). This was supported by the failure of $P$ content of siratro tops to reach the critical value of $0.24 \%$ (Andrew and Robins 1969) at any level of $P$ fertilizer on sandy soil. Grass competition for available $P$ supply could have prevented siratro from obtaining sufficient $\mathbf{P}$ for response, particularly in the establishment year. Given the low yield of siratro at all level of $P$ fertilizer, we do not recommend that this twining legume be sown to improve sandy soil rangelands in western Hainan.

Verano stylo pastures: For verano pastures, production exceeded $80 \%$ of the maximum yield on sandy soil $\left(8 \mathrm{t} \mathrm{ha}^{-1}\right.$ over 3 years) when available soil $P$ was increased to $>7 \mathrm{mg} \mathrm{kg}^{-1}$ by 
applying 28 to $56 \mathrm{~kg} \mathrm{ha}^{-1}$ of $\mathbf{P}$ fertilizer. This soil $\mathrm{P}$ level agrees with values reported as a requirement for stylo pasture to produce maximum cattle production on light-textured soils in northern Australia (Kerridge et al. 1990). The good response of verano to a relative low level of soil $P$ confirms the ability of the stylo to extract $P$ from infertile soils (Andrew and Robins 1969).

However, there is a danger that unless effective extension programs are put in place, this ability of stylos to produce yields consistently $>0.5 \mathrm{tha}^{-1}$ year $^{-1}$ (which far exceeds the legume content of unimproved rangeland) with little or no $P$ fertilizer, may entice Chinese peasants to dismiss the need to adequately fertilize such pastures and simply surface broadcasting stylo into unfertilized rangelands. This could have an adverse effect on the adoption rate of range improvement technology as livestock performance on such pastures will be well below expectations for 2 reasons.

First, the use of $100 \mathrm{~kg} \mathrm{ha}^{-1}$ of superphosphate every 3 to 5 years (a strategy often recommended based on Australian experience) would produce $<60 \%$ of the potential verano yield on sandy soil. More importantly, however, with low $\mathrm{P}$ fertilizer inputs, the $\mathrm{P}$ level in the tops was inadequate for the growth and reproduction of cattle (Call et al. 1978). Hall (1993) reported similar low P levels in verano grown on light-textured soils in northern Australia, and suggested that a $P$ supplement would be needed for breeders to gain the most benefit from the legume complement.

Based on the $P$ requirements for grazing cattle, the large initial $P$ requirement predicted by the LRP model for verano pastures (43 $\mathrm{kg} \mathrm{P} \mathrm{ha}^{-1}$ ) should provide adequate $P$ for 2 years as well as improve the nitrogen status of companion grasses. Economic analyses (D.L. Michalk, unpublished), show that at this rate, the marginal net return was about $\$ 1.5$ per dollar invested in fertilizer. Only when there was a concurrent $50 \%$ increase in the cost of $P$ and a similar decrease in the price of carcass beef did the analysis indicate that it was too risky to fertilize stylo pastures at the optimum rate.

$P$ recovery rate: $\mathrm{P}$ recovery at low fertilizer rates was significant, but still more than half of the applied $P$ remained unaccounted for even when a $25 \%$ allowance was made for the $\mathrm{P}$ content of roots. The lack of difference in the $\mathrm{P}$ status of soil between verano- and siratro-based pastures at the end of the study even though verano pastures extracted more $P$, suggests that leaching may account for the loss of the remaining fertilizer $P$. In general, $P$ loss from most soils is negligible (Sanchez 1976), but extremely sandy soils are notable exceptions. On sandy soil in northern Australia, for example, Gillman (1973) showed that more than $50 \%$ of applied $P$ was leached from top-soil $(30 \mathrm{~cm})$ under rainfall of $1,145 \mathrm{~mm} \mathrm{yr}^{-1}$. These results suggest that significant $P$ loss by leaching is possible on Gaopoling sands given the soil charac-

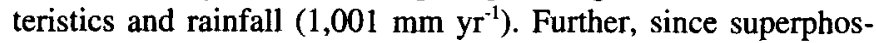
phate is highly soluble, most leaching is likely to occur in the first wet season following fertilizer application.

\section{Non-responsive loam soil}

In contrast to the strong curvilinear response observed on sandy soil, no significant response was measured in either total or legume yield to increasing rates of $P$ fertilizer on loam soil at Gaopoling Farm. The response is indicative of a soil with a native $P$ level exceeding the critical value for target pasture species (Sanchez 1976). This lack of response verifies soil tests and missing element studies which showed $P$ sufficiency on loam soil.

Poor performance of both legumes in 1983, resulted from a wildfire which burnt the loam soil area 3 months before the 1983 harvest. This did not affect the density of either species in the following wet season (Zhu Ching-Ming, unpublished data), but it did reduce legume production by bestowing a competitive advantage on Imperata cylindrica, a fire-tolerant grass, which made rapid regrowth using nutrients released by burning. It also shaded the slower growing, shade-intolerant stylo (Sillar 1967).

Based on responses measured in these experiments, there is no immediate bencfit either in total production or increased legume component to warrant fertilizer application to either stylo- or siratro-based pastures grown on loam soil. However, while siratro yielded less than verano on loam soil, we recommend that siratro be sown on loam soil areas as it is more compatible with introduced grasses (eg. Setaria sphacelata) which are also recommended for this soil type (Michalk et al. 1993b).

\section{Conclusion}

Given limited supplies of superphosphate for use on rangelands in south China, these results from Gaopoling Farm demonstrated that there was no benefit gained from applying $P$ fertilizer to pastures grown on soils with an available soil $P$ level exceeding 20 $\mathrm{mg} \mathrm{kg}^{-1}$. In contrast, dry matter responses, recovery rates of fertilizer $\mathbf{P}$, and possible large losses of applied $\mathrm{P}$ through leaching have important implications for developing $P$ fertilizer strategies for sandy soils in south China. While the application of a large amount of superphosphate ( $>28 \mathrm{~kg} \mathrm{P} \mathrm{ha} \mathrm{a}^{-1}$ ) in a single application was sufficient to maintain both yield and $P$ content of verano stylo, split applications of the same total amount or additional maintenance inputs may further increase the production of legumes and companion grasses on sandy soils.

\section{Literature Cited}

Andrew, C.S. and M.F. Robins. 1969. The effect of phosphorus on the growth and chemical composition of some tropical pasture legumes. 1. Growth and critical percentages of phosphorus. Aust. J. Agr. Res. 20:665-674.

Andrew, C.S. and M.F. Robins. 1971. The effect of phosphorus on the growth, chemical composition and critical phosphorus percentages of some tropical pasture grasses. Aust. J. Agr. Res. 22:693-706.

Call, J.W., J.E. Butcher, J.T. Blake, R.A. Smart, and J.L. Shupe. 1978. Phosphrous influence on growth and reproduction of beef cattle. J. Anim. Sci. 47:216-225.

Gillman, G.P. 1973. Studies on some deep sandy soils in Cape York Peninsula, Northern Queensland. 3. Losses of applied phosphorus and sulphur. Aust. J. Exp. Agr. Anim. Husb. 13:418-422.

Hall, T. 1993. Response of Stylosanthes hamata cv. Verano and native pastures to fertilisers on two light-textured soils in north-west Queensland. Trop. Grassl. 27:75-86.

Hong, Fu-Zeng. 1985. Studies on the tropical and subtropical pasture resources and their exploitation prospects in China. Trop. Agr. Res. $18: 1-8$.

Hu, Shing Tsung, D.B. Hannaway, and H.W. Youngberg. 1992. Forage Resources of China. Pudoc Wageningen.

Jiang, Bai-Fan, Lu Ru-Kun, and Li Chiang-Kwei. 1981. Status and transformation of phosphorus in tropical soils of China with special reference to effective dressing of phosphatic fertilizers, p. 101-111. In: E. Puspharajah and Sharifuddin H.D. Hamid (eds.) Phosphorus and potassium in the tropics. Proc. Int. Conf. on Phosphorus and Potassium in the Tropics, Kuala Lumpur, Malaysia, 17-19 August, 1981.

Jones, R.J. and R.M. Jones. 1976. The ecology of siratro-based pastures, p. 353-367. In: J.R. Wilson (ed.) Plant relations in pastures. CSIRO/Elsevier, Melbourne. 
Kerridge, P.C., M.A. Gilbert, and D.B. Coates. 1990. Phosphorus and beef production in northern Australia. 8. The status and management of soil phosphorus in relation to beef production. Trop. Grassl. 24:221-230.

Michalk, D.L., Fu Nan Ping, and Zhu Chin-Ming. 1993a. Improvement of dry tropical rangelands in Hainan Island, China: 1. Evaluation of pasture legumes. J. Range Manage. 46:331-339.

Michalk, D.L., Fu Nan Ping, and Zhu Chin-Ming. 1993b. Improvement of dry tropical rangelands in Hainan Island, China: 2. Evaluation of pasture grasses. J. Range Manage. 46:339-345.

Payne, R.W. and Committee. 1988. Genstat 5 Reference Manual. Oxford. Univ. Press, Oxford, England.

Probert, M.E. and J. Williams. 1986. Effect of phosphorus application on seasonal changes in nitrogen and phosphorus concentrations of four perennial Stylosanthes accessions. Aust. J. Exp. Agr. 26:49-58.

Rees, M.C., R.M. Jones, and R.Roe. 1976. Evaluation of pasture grasses and legumes in mixtures in south-east Queensland. Trop. Grassl. 10:65-78.

Sanchez, P.A. 1976. Properties and management of soils in the tropics. John Wiley \& Sons, New York.
Sanchez, P.A. and J.G. Salinas. 1981. Low-input technology for managing Oxisols and Ultisols in tropical America. Adv. Agron. 34:279-406.

Sillar, D.I. 1967. Effect of shade on growth of Townsville stylo (Stylosanthes humilis H.B.K.). Qld. J. Agr. Anim. Sci. 24:237-240.

Winks, L.W., J.C. Lamberth, K.W. Moir, and P.M. Pepper. 1974. Effect of stocking rate and fertilizer on the performance of steers grazing Townsville stylo based pasture in north Queensland. Aust. J. Exp. Agr. Anim. Husb. 14:146-154.

Winter, W.H., J.J. Mott, R.W. McLean, and D. Ratcliff. 1989a. Evaluation of management options for increasing the productivity of tropical savanna pastures. 1. Fertilisers. Aust. J. Exp. Agr., 29:613-622.

Winter, W.H., J.J. Mott, R.W. McLean, and D. Ratcliff. 1989b. Evaluation of management options for increasing the productivity of tropical savanna pastures. 2. Legumes. Aust. J. Exp. Agr. 29:623-630.

Zhao Qi-Guo and Shi Hua. 1986. On the genesis, classification and characteristics of the soils in tropical and subtropical China, p. 197 228. In: C.K. Li (ed-in-ch.), Proc. Int. Sym. Red Soils, Sci. Press, Beijing, China. 